\title{
Article
}

\section{A Novel Thermostable Keratinase from Deinococcus geothermalis with Potential Application in Feather Degradation}

\author{
Yin Tang ${ }^{1}$, Leizhou Guo ${ }^{1}$, Mingming Zhao ${ }^{2}$, Yuan Gui ${ }^{1}$, Jiahui Han ${ }^{2}$, Wei Lu ${ }^{2}$, Qilin Dai ${ }^{1}$, Shijie Jiang ${ }^{1}$, \\ Min Lin ${ }^{2}$, Zhengfu Zhou ${ }^{2, *}$ and Jin Wang ${ }^{1,2, *}$ \\ 1 School of Life Science and Engineering, Southwest University of Science and Technology, \\ Mianyang 621000, China; tangyin15280939267@163.com (Y.T.); guoleizhou102819@163.com (L.G.); \\ gui_yuan2021@163.com (Y.G.); daiqilinmj@sina.com (Q.D.); sjjiang0406@swust.edu.cn (S.J.) \\ 2 Biotechnology Research Institute, Chinese Academy of Agricultural Sciences, Beijing 100081, China; \\ 82101182064@caas.cn (M.Z.); 13121257599@163.com (J.H.); luwei01@caas.cn (W.L.); \\ linmin57@vip.163.com (M.L.) \\ * Correspondence: zhouzhengfu@caas.cn (Z.Z.); wangjin@caas.cn (J.W.)
}

check for updates

Citation: Tang, Y.; Guo, L.; Zhao, M.; Gui, Y.; Han, J.; Lu, W.; Dai, Q.; Jiang, S.; Lin, M.; Zhou, Z.; et al. A Novel Thermostable Keratinase from Deinococcus geothermalis with Potential Application in Feather Degradation. Appl. Sci. 2021, 11, 3136 https://doi.org/10.3390/ app11073136

Academic Editor: Hoon Kim

Received: 12 March 2021

Accepted: 28 March 2021

Published: 1 April 2021

Publisher's Note: MDPI stays neutral with regard to jurisdictional claims in published maps and institutional affiliations.

Copyright: (c) 2021 by the authors. Licensee MDPI, Basel, Switzerland. This article is an open access article distributed under the terms and conditions of the Creative Commons Attribution (CC BY) license (https:// creativecommons.org/licenses/by/ $4.0 /)$.
Abstract: Keratinase can specifically attack disulfide bridges in keratin to convert them from complex to simplified forms. Keratinase thermal stability has drawn attention to various biotechnological industries. In this study, a keratinase DgeKer was identified from a slightly thermophilic species, D. geothermalis. The in silico analysis showed that DgeKer is composed of signal peptide, $\mathrm{N}$-terminal propeptide, mature domain, and C-terminal extension. DgeKer and its C-terminal extension-truncated enzyme (DgeKer-C) were cloned and expressed in E. coli. The purified DgeKer and DgeKer-C showed maximum activity at $70{ }^{\circ} \mathrm{C}$ and $\mathrm{pH}$ 9-The thermal stability assay $\left(60{ }^{\circ} \mathrm{C}\right)$ showed that the half-life value of DgeKer and DgeKer-C were $103.45 \mathrm{~min}$ and $169.10 \mathrm{~min}$, respectively. DgeKer and DgeKer-C were stable at the range of $\mathrm{pH}$ from 9 to 11 and showed good tolerance to some metal ions, surfactants and organic solvent. Furthermore, DgeKer could degrade feathers at $70{ }^{\circ} \mathrm{C}$ for $60 \mathrm{~min}$. However, the medium became turbid with obvious softening of barbules after being treated with DgeKer-C, which might be due to C-terminal extension. In summary, a thermostable keratinase DgeKer with high efficiency degradation of feathers may have great potential in industry.

Keywords: Deinococcus geothermalis; keratinase; thermostability; feather degradation; C-terminal extension

\section{Introduction}

Keratinase (EC3.4.21/24/99.11) is a class of enzymes that can specifically degrade keratin, which is a structural protein used by animals for mechanical protection with sulfur-containing compounds and disulfide bonds. It can degrade feathers and other difficult-to-degrade keratinous substances with low energy consumption and environmental friendliness, which has application potential in husbandry [1,2], medical [3-5], cosmetics, biological materials [6] and other industries. Keratin is widely found in agricultural waste, especially bird feathers from poultry processing plants [7], and urgently needs to be processed and recycled. In the process of feather degradation, higher temperatures are favorable for the destruction of disulfide bonds in keratin, which improves hydrolysis efficiency. However, high temperature will destroy the non-covalent interaction of proteins and eventually lead to enzyme inactivation. Keratinolytic thermophilic or hyperthermophilic bacteria and archaea have been known to degrade keratin at $\geq 70{ }^{\circ} \mathrm{C}$ [8]. At present, many keratinases have been identified from microorganisms, but the number of keratinases used in the market is very small, which might be related to the thermal stability of keratinases [9]. Therefore, it is very important to find and identify high temperature-adaptive keratinases.

In order to find thermally stable keratinases, researchers tend to isolate keratinase bacteria from a high-temperature environment, such as hyperthermophilic archaeon Thermococcus kodakaraensis [10], the thermophile strain Meiothermus taiwanensis WR-220 (isolated 
from hot springs) [11], etc. The optimal temperature and $\mathrm{pH}$ of keratinase MtaKer from M. taiwanensis WR-220 are $65{ }^{\circ} \mathrm{C}$ and $\mathrm{pH} 10$, respectively. MtaKer has keratinase activity in a larger temperature and $\mathrm{pH}$ range. In extreme environments, the protein encoded by extremophiles should evolve into functional proteins to adapt to the environment. The strong tolerance of Mtaker may be related to the extreme living environment of $M$. taiwanensis WR-Many recent studies have focused on extremozymes, especially the high temperature-resistant enzymes, because adjustment to industrial harsh conditions needs the activity and stability of the applied enzymes in such conditions [12,13]. Since evolution and natural selection have occurred in the environment for billions of years, extreme bacteria may produce customized enzymes with some unique properties required for industrial applications. Deinococcus bacteria are famous for their radiation tolerance, however, the peptidase genes present in their genome are ignored. D. geothermalis was discovered in hot springs, and the optimal growth temperature of D. geothermalis is $50{ }^{\circ} \mathrm{C}$, higher than the growth temperature of medium-temperature bacteria. The enzymes of $D$. geothermalis might have good tolerance to extreme industrial conditions, especially thermostability.

In this study, the keratinase gene Dgeo_0978, named dgeKer, was identified from the D. geothermalis genome. The keratinase DgeKer (GenBank No. WP_011530115.1) from D. geothermalis was successfully expressed and purification in E. coli BL21-codonplus (DE3) strains. The biochemical properties of the recombinant enzyme and the ability in degrading feathers were examined. The results showed that DgeKer had high activity under high temperature and $\mathrm{pH}$ conditions, which making it a promising enzyme for industry.

\section{Materials and Methods}

\subsection{Strains, Plasmids and Materials for Gene Cloning and Expression}

Deinococcus geothermalis DSM 11300 was cultured at $50{ }^{\circ} \mathrm{C}$ for $24 \mathrm{~h}$ in TGY media (10 g/L typtone, $1 \mathrm{~g} / \mathrm{L}$ glucose, $5 \mathrm{~g} / \mathrm{L}$ yeast extract) [14]. E. coli BL21-codonplus (DE3) was cultured in Luria-Bertani (LB) at $37^{\circ} \mathrm{C}$. The vector $\mathrm{pET} 22 \mathrm{~b}$ was used for expression of keratinase genes in E. coli BL21-codonplus. All the enzymes for DNA manipulations were purchased from vazyme (Nanjing, China). All chemicals used in this study were of reagent grade.

\subsection{Sequence Analysis}

The gene sequence of DgeKer was analyzed by the NCBI (National Center for Biotechnology Information) and InterPro. The signal peptide prediction was performed by the SignalP 5.0 server. The alignment analysis of amino acid sequences was performed by ESPript3.The phylogenetic tree of protein sequences was constructed by MEGA 6.0 with the neighbor-joining (NJ) method.

\subsection{Plasmids Construction}

The genome of D. geothermalis was used as a DNA template for the DgeKer gene cloning. The keratinase genes without the signal sequence were PCR amplified using $2 \times$ phanta max master mix with the instructions and the primers in Table 1 The amplified fragments were cloned into a pET22b expression vector (Novagen) containing the Cterminal His-tag using vazyme ClonExpress Ultra One Step Cloning Kit. The correctly recombinant plasmids were transformed into E. coli BL21-codonplus (DE3) competent cells for gene expression. The construction of the keratinase without $\mathrm{C}$-terminal extension (DgeKer-C) was the same as DgeKer. 
Table 1. Primers used in this study.

\begin{tabular}{|c|c|}
\hline Genes & Primer Sequences $\left(5^{\prime}\right.$ to $\left.3^{\prime}\right)$ \\
\hline \multirow{2}{*}{ dgeKer } & F1: 5'tcgagctccgtcgacaagcttATGTGCGGACAGCAGGCGAAT \\
\hline & R1: 5' gtggtggtggtggtgctcgagCTTCGTCTCGACCAGGGTGTA \\
\hline \multirow{2}{*}{ dgeKer-C } & F1: $5^{\prime}$ tcgagctccgtcgacaagcttATGTGCGGACAGCAGGCGAAT \\
\hline & R2: 5' gtggtggtggtggtgctcgagGGTGTAGAGCAGGCGGTTGG \\
\hline
\end{tabular}

The lowercase letters indicate pET22b vector homology arms.

\subsection{Expression and Purification of Keratinases}

The induction and purification of keratinases was carried out according to Cheng Zhou et al. [15] with some modification. E. coli BL21-codonplus harboring pET22b-DgeKer was used for recombinant keratinase production. The recombinant $E$. coli was cultured overnight at $37^{\circ} \mathrm{C}$ in $20 \mathrm{~mL}$ of LB medium containing $50 \mu \mathrm{g} / \mathrm{mL}$ of ampicillin (Amp) and $34 \mu \mathrm{g} / \mathrm{mL}$ of chloroamphenicol $(\mathrm{Cm})$. The cultures were transferred into $150 \mathrm{~mL}$ of fresh medium and induced with $0.1 \mathrm{mM}$ isopropyl- $\beta$-D-thiogalactopyranoside (IPTG) at $\mathrm{OD}_{600}=0.6-0.8$, followed by overnight expression at $16^{\circ} \mathrm{C}$. The cells were harvested by centrifugation at $4000 \times g$ for $15 \mathrm{~min}$ and resuspended with Tris- $\mathrm{HCl}$, and disrupted on ice by an ultrasonicator. The debris was removed by centrifugation at $12,000 \times g$ for $30 \mathrm{~min}$. The recombinant keratinases were purified by Ni-affinity chromatography (Qiagen) and eluted with an increasing imidazole gradient. The molecular weight of purified DgeKer was determined by sodium dodecyl sulfate polyacrylamide gel electrophoresis (SDS-PAGE).

\subsection{Keratinolytic Activity Assay}

Keratinolytic activity was measured with soluble keratin through the modified method by Jin-Song Gong [16]. Soluble keratin was purchased from Tokyo Chemical Industry (Tokyo, Japan). The reaction mixture, which contained $20 \mu \mathrm{L}$ enzyme, $80 \mu \mathrm{L}$ buffer and $100 \mu \mathrm{L}$ soluble keratin $(1 \%, w / v)$, was incubated at $50{ }^{\circ} \mathrm{C}$ for $20 \mathrm{~min}$. A blank control was conducted by adding $200 \mu \mathrm{L}$ of $20 \%(w / v)$ trichloroacetic acid (TCA) instead of soluble keratin. The reaction was terminated by the addition of $200 \mu \mathrm{L}$ TCA, and centrifuged at $12,000 \mathrm{rpm}$ for $10 \mathrm{~min}$. We added $100 \mu \mathrm{L}$ soluble keratin to the control mixture. Then, $200 \mu \mathrm{L}$ supernatant was pipetted into another tube with $1 \mathrm{~mL} 0.4 \mathrm{~mol} / \mathrm{L} \mathrm{Na}_{2} \mathrm{CO}_{3}$ and $200 \mu \mathrm{L}$ Folin-phenol regent. Finally, the mixtures were incubated at $40^{\circ} \mathrm{C}$ for $20 \mathrm{~min}$ to develop the color. Proteolytic products in the mixture were measured spectrophotometrically at $680 \mathrm{~nm}$. One unit (U) of keratinase activity was defined as an increase of 0.01 absorbance unit at $680 \mathrm{~nm}$ under the aforementioned conditions. All assays were performed in triplicate.

The determination of feather powder activity was carried out according to Lian Yang et al. [17] with some modification. The reaction system including $4 \mathrm{~mL}$ buffer, $0.01 \mathrm{~g}$ feather powder and $200 \mu \mathrm{L}$ enzyme with $5 \mathrm{mmol} / \mathrm{L}$ dithiothreitol (DTT) was incubated at $70{ }^{\circ} \mathrm{C}$ for $60 \mathrm{~min}$ and subsequently terminated by adding $2.0 \mathrm{~mL}$ of $20 \% \mathrm{TCA}$. After centrifugation at $12,000 \times g$ for $5 \mathrm{~min}$, the supernatant was gathered for measuring the absorbance at $280 \mathrm{~nm}$. TCA (20\%) was added before the enzymatic reaction as the control. One unit (U) of feather powder activity was defined as an increase of 0.01 absorbance unit at $280 \mathrm{~nm}$. All assays were performed in triplicate. Protein concentration was determined using the Bradford method with bovine serum albumin as a standard.

\subsection{Effects of $\mathrm{pH}$, Temperature, and Reagents on Enzyme Activity and Stability}

The optimal reaction temperature of DgeKer and DgeKer-C was investigated in the temperature range $30-90^{\circ} \mathrm{C}$, and the optimal $\mathrm{pH}$ experiment was carried out over a $\mathrm{pH}$ range of 3-11 ( $\mathrm{pH} 3.0-6.0,50 \mathrm{mmol} / \mathrm{L}$ citrate buffer, $\mathrm{pH} 7-9,50 \mathrm{mmol} / \mathrm{L}$ Tris-HCl, $\mathrm{pH} 10-11$, $50 \mathrm{mmol} / \mathrm{L}$ Gly-NaOH), using $1 \%$ soluble keratin. In thermostability assays, enzymes were pre-incubated at temperatures of $30^{\circ} \mathrm{C}$ to $80^{\circ} \mathrm{C}$ for $1 \mathrm{~h}$, and residual enzyme activities was determined. The $\mathrm{pH}$ stability was measured by pre-incubating DgeKer and DgeKer-C in different $\mathrm{pH}$ solutions at $4{ }^{\circ} \mathrm{C}$ for $1 \mathrm{~h}$, and then the residual activities were detected. 
The effect of metal ions on enzyme activity was analyzed by assaying the relative activity with addition of $1.0 \mathrm{mmol} / \mathrm{L}$ and $5.0 \mathrm{mmol} / \mathrm{L}$ of metal ions $\left(\mathrm{K}^{+}, \mathrm{Li}^{+}, \mathrm{Mn}^{2+}, \mathrm{Cu}^{2+}\right.$, $\left.\mathrm{Fe}^{2+}, \mathrm{Ca}^{2+}, \mathrm{Co}^{2+}, \mathrm{Mg}^{2+}, \mathrm{Ni}^{2+}, \mathrm{Cd}^{2+}, \mathrm{Cr}^{3+}\right)$. Similarly, the effect of some surfactants and organic solvent on enzyme activity were also analyzed. We added $1 \%$ dimethyl sulfoxide (DMSO), $1 \% \beta$-mercaptoethanol, $1 \%$ tween-20, 1\% tween- 80 and $1 \%$ sodium dodecyl sulfate (SDS) $(v / v)$ for the relative activity evaluation.

\subsection{Chicken Feather Degradation In Vitro}

Chicken feathers degradation was carried out according to Yaxin Ren [18] with some modifications. Chicken feather was previously washed and cleaned with detergent and tap water, followed by soaking in $70 \%$ ethanol for $1 \mathrm{~h}$ and drying. After that, it was autoclaved at $121^{\circ} \mathrm{C}$ for $30 \mathrm{~min}$ to remove microorganisms for following use. The intact chicken feathers were incubated with $0.06 \mathrm{mg}$ enzyme at $70{ }^{\circ} \mathrm{C}$ with $5 \mathrm{mmol} / \mathrm{L}$ DTT. The degradation process of feathers was recorded regularly.

\subsection{Statistical Analysis}

The results were analyzed with GraphPad Prism 8.0.2 and SPSS Statistics 25 software. Differences in means between groups were compared for statistical significance at $p<0.05$.

\section{Results}

\subsection{Sequence Analysis of DgeKer}

The gene dgeKer (1545 bp) encodes a protein comprising 514 amino acids with a calculated mass of $50.0 \mathrm{kDa}$. The amino acid sequence of DgeKer was compared with those of keratinases, which were KerA from Bacillus licheniformis PWD-1, MtaKer from M. taiwanensis WR-220 and aqualysin-I from Thermus aquaticus YT-1 in Figure 1 It was proposed that DgeKer consists of four parts, including signal peptide (Pre), N-terminal pro-peptide (N-pro), mature domain with a three highly conserved catalytic triad residues which is formed by Asp171, His203 and Ser354 (black frame). Additionally, DgeKer has a C-terminal extension like the thermophilic alkaline serine protease aqualysin-I, while the classic keratinase KerA does not contain a C-terminal extension.

Phylogenetic analysis of DgeKer and other homologous proteins was constructed based on DgeKer protein sequence. As shown in Figure 2, the DgeKer showed significant relatedness to peptidase from Deinococcus bacteria: they were localized at the same branch in the phylogenetic tree, indicating a common evolutionary origin. In addition, DgeKer had a certain homology with the keratinase from the Thermus, such as aqualysin I (WP_053768483.1) derived from Thermus aquaticus, with 53.49\% identity. The protein sequence of DgeKer displayed similarity to MtaKer from M. taiwanensis WR-220 (GenBank No. AWR86689.1) and KerA (GenBank No. AAB34259.1) from Bacillus licheniformis with $58.96 \%$ and $40.20 \%$ identity, respectively. Based on the phylogenetic tree and sequence identity analysis, we concluded that DgeKer is a keratinase.

\subsection{Expression and Purification of Recombinant DgeKer and DgeKer-C}

E. coli is an ideal strain for protein heterologous expression. In order to obtain purified DgeKer and DgeKer-C (truncated form of the DgeKer without the C-terminal extension), recombinant plasmids carrying keratinase genes without signal peptide were constructed for E. coli expression system. As shown in Figure 3, DgeKer and DgeKer-C were expressed in E. coli BL21-codonplus (DE3) strains and purified successfully. The cloned DgeKer and DgeKer-C have expected molecular weight of $50.0 \mathrm{kDa}$ and $38.4 \mathrm{kDa}$, respectively. However, the protein bands were detected in the SDS-PAGE after purification by Ni-affinity chromatography and migrated at approximately $38 \mathrm{kDa}$ and $27 \mathrm{kDa}$, which correspond to the molecular mass of the mature keratinases without N-propeptide. Beside the major bands, protein bands at lower molecular weights (approximately 10-15 kDa) were detected. 

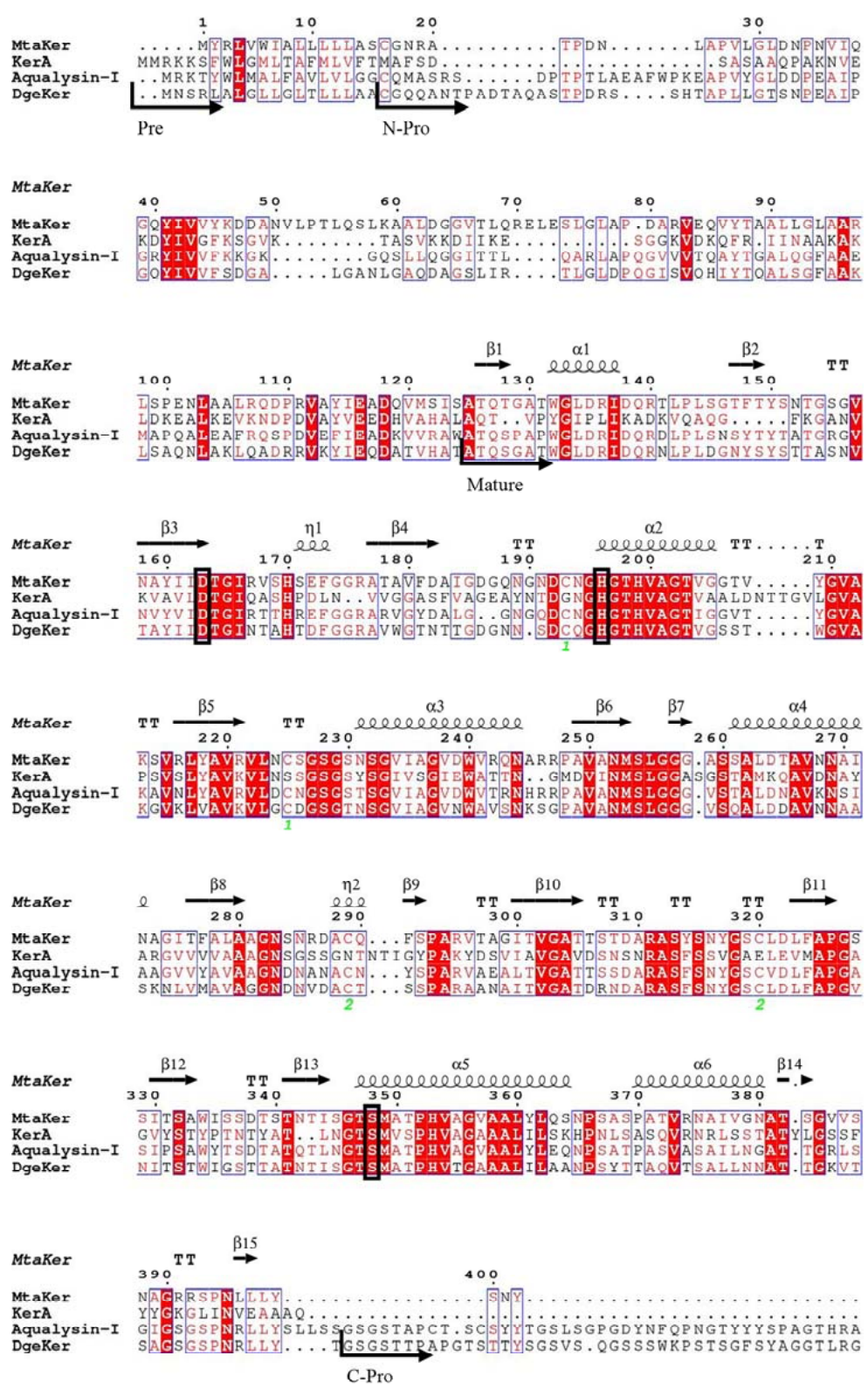

MtaKer

MtaKer

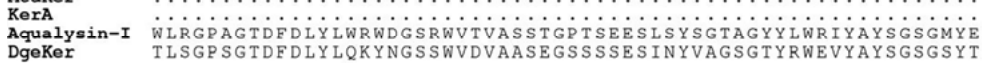

Mtaker

MtaKer $\begin{array}{ll}\text { KerA } & \text { Aqualysin-I } \\ \text { DgeKer } & \text { FWLQRP } \\ \text { LVETK }\end{array}$

Figure 1. Alignment of the amino acid sequences of DgeKer. The keratinases used were KerA from B. licheniformis PWD-1, MtaKer from M. taiwanensis WR-220, etc. Sequence alignment showing structural elements of DgeKer were generated with ESPript3.The identical residues of all aligned proteins are shaded red, conserved residues are presented in red, and conserved regions are presented in blue boxes. $\alpha, \beta, \eta$, TT above the sequences represent $\alpha$ helix, $\beta$ sheet, 310-helices and $\beta$-turns, respectively. Positions of the starting residues of the signal peptide (pre), $\mathrm{N}$-terminal pro-peptide ( $\mathrm{N}$-pro), mature protease (mature), and C-terminal pro-peptide (C-pro) are marked by black arrows at the bottom of the sequences. 


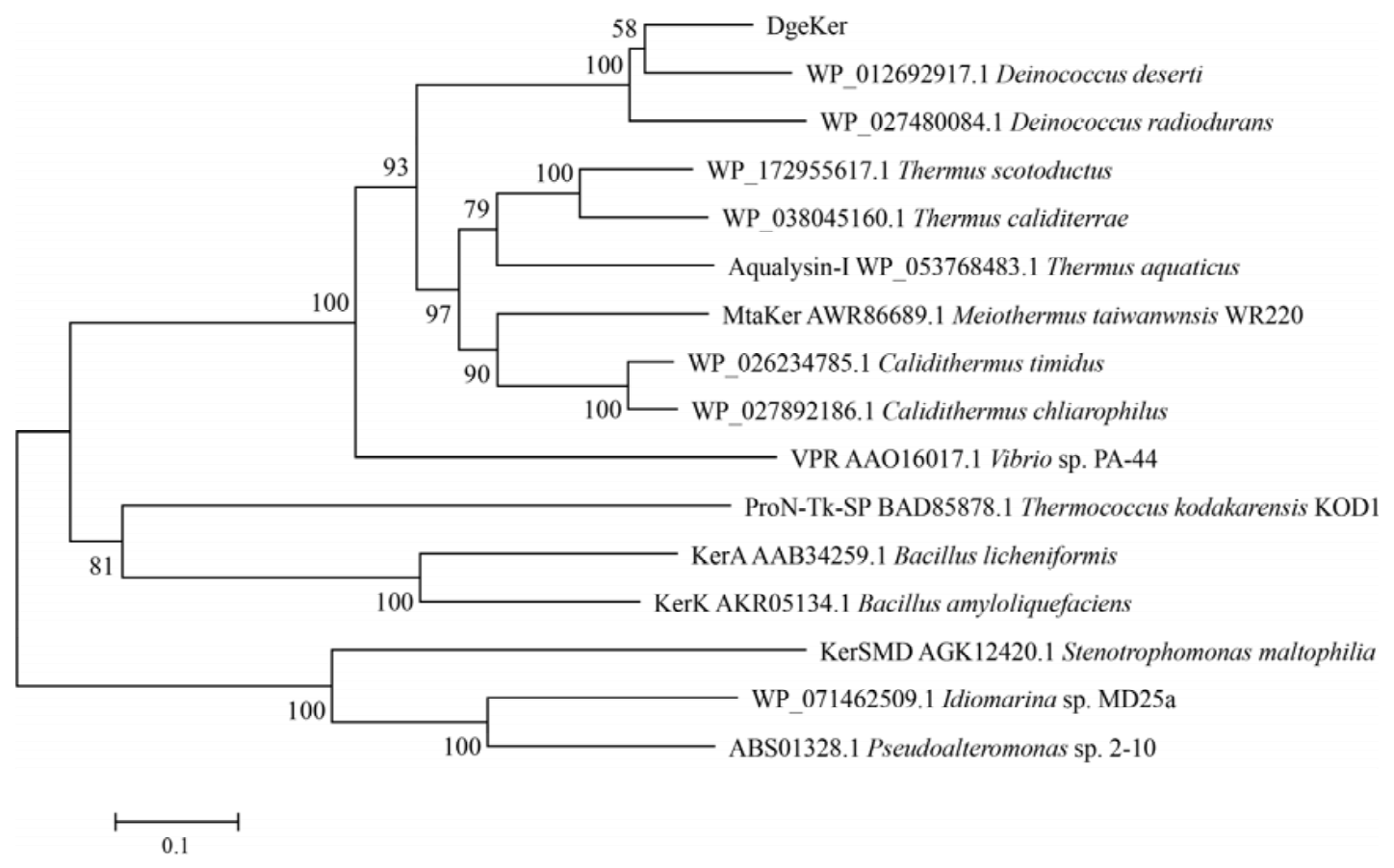

Figure 2. Phylogenetic analysis of amino acid sequence of keratinases. The keratinases used were KerA from B. licheniformis PWD-1, MtaKer from M. taiwanensis WR-220 and other homologous protein based on amino acid sequences. The name and GenBank accession No. for each protease are in front of the Latin name of each strain. The phylogenetic tree derived by the neighbor-joining method. The percentages of replicate trees in which the associated taxa clustered together in the bootstrap test (1000 replicates) are shown next to the branches.

(a)

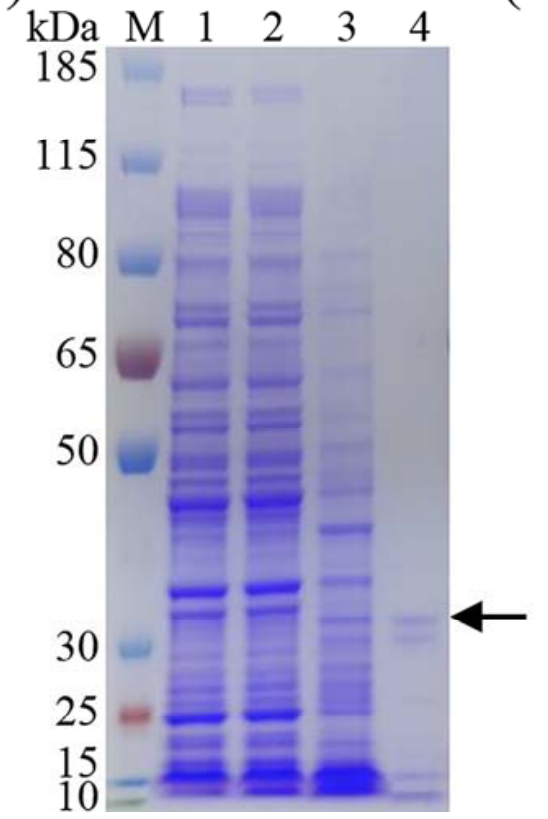

(b)

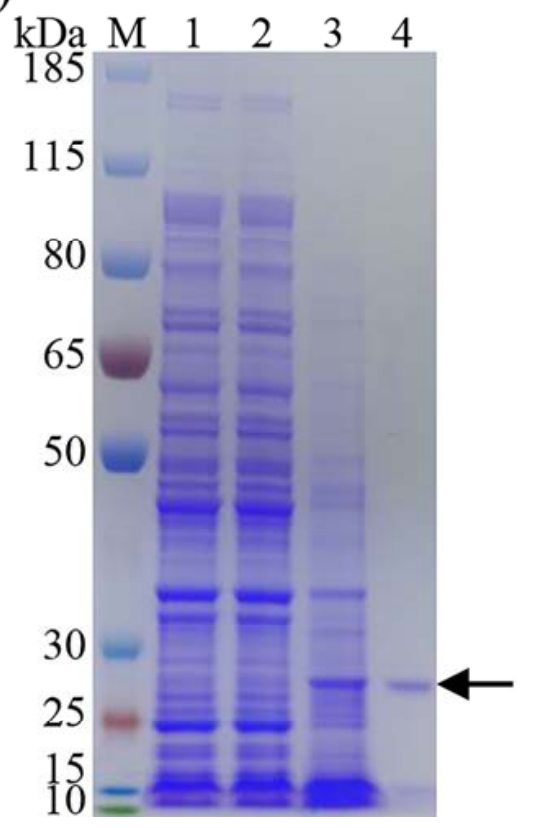

Figure 3. Sodium dodecyl sulfate polyacrylamide gel electrophoresis (SDS-PAGE) analysis of DgeKer (a) and DgeKer-C (b). (a) M, protein MW maker; lane 1, E. coli BL21-codonplus (DE3) harboring pET22b for control; lane 2, pET22b-DgeKer for control; lane 3, DgeKer crude extract; lane 4, purified keratinase DgeKer (arrow). (b) M, protein MW maker; lane 1, E. coli BL21-codonplus (DE3) harboring pET22b for control; lane 2, pET22b-DgeKer-C for control; lane 3, DgeKer-C crude extract; lane 4, purified keratinase DgeKer-C (arrow). 


\subsection{Effects of Temperature and $\mathrm{pH}$ on Activity and Stability}

In order to characterize the recombinant keratinases, the effects of temperature and $\mathrm{pH}$ on the recombinant keratinases was determined in this study. We used $1 \%$ soluble keratin to measure the enzyme activity. As shown in Figure 4, the optimal temperature of DgeKer and DgeKer-C were $70^{\circ} \mathrm{C}$. Moreover, the thermostability of DgeKer and DgeKer-C was also characterized. The residual activity of DgeKer after being incubated at $60{ }^{\circ} \mathrm{C}$ for 90 min was approximately $54 \%$, and that of DgeKer-C was $69 \%$, indicating that both of them have thermal stability. As shown in Table 2, the half-life $\left(t_{1 / 2}\right)$ of DgeKer at $60{ }^{\circ} \mathrm{C}$ was $103.45 \mathrm{~min}$, which was longer than that of KerA (26.46 $\mathrm{min}$ ) but shorter than that of DgeKer-C (169.10 min). At $70{ }^{\circ} \mathrm{C}$, DgeKer-C also exhibited better temperature stability than DgeKer. Unfortunately, KerA completely lost its enzymatic activity after being incubated at $70^{\circ} \mathrm{C}$ for $20 \mathrm{~min}$ (Figure $4 \mathrm{c}$ ). In terms of $\mathrm{pH}$, the effects of $\mathrm{pH}$ to DgeKer and DgeKer-C was about the same (Figure $4 \mathrm{~b}$ ). DgeKer and DgeKer-C showed maximum activity at around $\mathrm{pH}$ 9-DgeKer and DgeKer-C were sensitive in the range of $\mathrm{pH} 3-7$, while they were stable in range of 8-DgeKer and DgeKer-C had approximately the whole activity after being treated at $\mathrm{pH} 11$ for $60 \mathrm{~min}$. The date appears to suggest that DgeKer and DgeKer-C have potential industry application, due to their outstanding thermostability and $\mathrm{pH}$ stability.

(a)

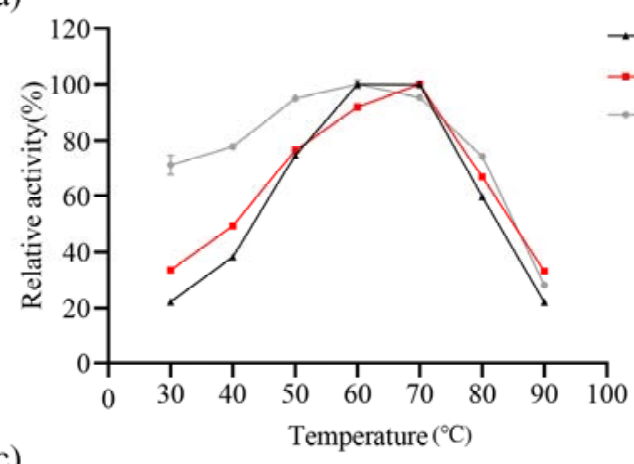

(c)

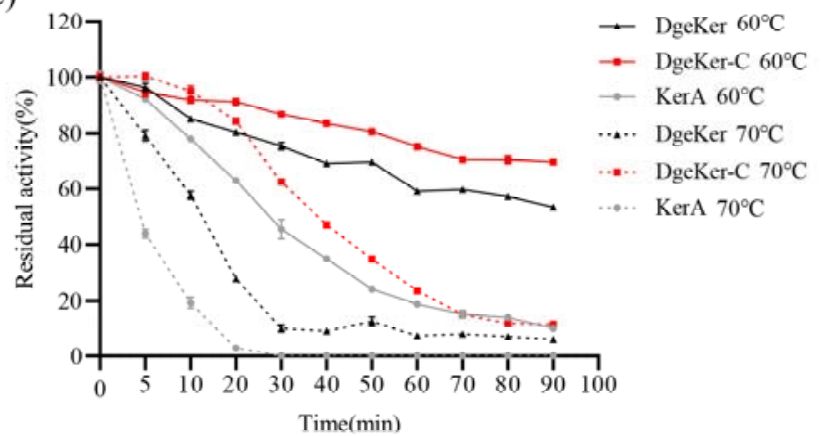

(b)

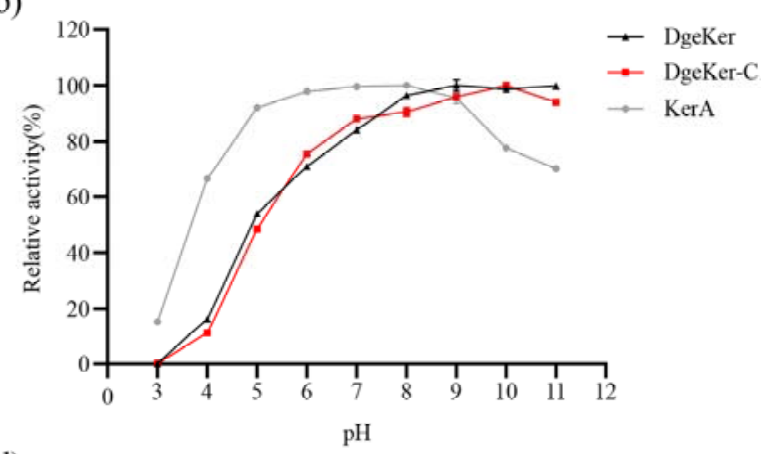

(d)

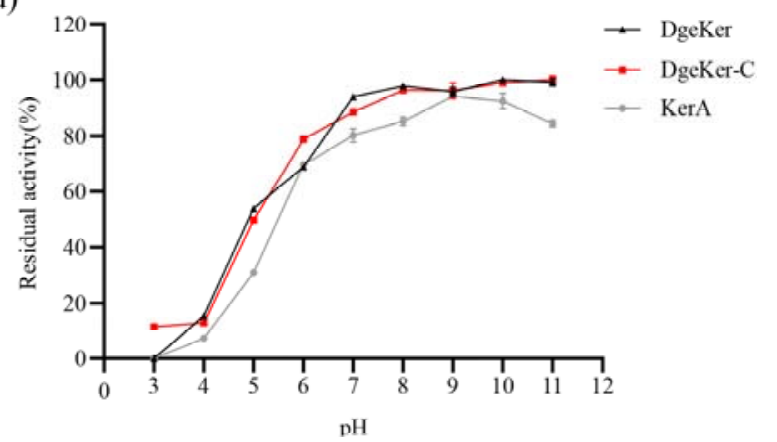

Figure 4. Effects of temperature and pH on keratinase activity of DgeKer, DgeKer-C and KerA. (a) The effects of temperature for DgeKer, DgeKer-C and KerA. (b) The effects of pH for DgeKer, DgeKer-C and KerA. (c) The thermostability for DgeKer, DgeKer-C and KerA. (d) The pH stability for DgeKer, DgeKer-C and KerA. The filled triangle represents DgeKer, and the filled square represents DgeKer-C. Error bars represent standard deviations.

Table 2. The half-life of DgeKer and DgeKer-C at $60{ }^{\circ} \mathrm{C}$.

\begin{tabular}{cc}
\hline Keratinases & $\mathbf{t}_{\mathbf{1 / 2}}$ (min) \\
\hline DgeKer & $103.45 \pm 1.26^{\mathrm{b}}$ \\
DgeKer-C & $169.10 \pm 8.20^{\mathrm{c}}$ \\
KerA & $26.46 \pm 0.22^{\mathrm{a}}$ \\
\hline
\end{tabular}

Superscript letter ${ }^{a, b, c}$ down the column were used to indicate significant difference at $p<0.05$. 
As shown as in Table 3, recombinant keratinases DgeKer and DgeKer-C showed the same capabilities to hydrolyze soluble keratin and feather powder. With soluble keratin as substrate, DgeKer and DgeKer-C showed highest specific activity of $40,192.30 \pm 230.48 \mathrm{U} / \mathrm{mg}$ and 40,408.89 $\pm 342.73 \mathrm{U} / \mathrm{mg}$, respectively. DgeKer and DgeKer$\mathrm{C}$ had almost the same enzyme activity on feather powder, approximately $1450 \mathrm{U} / \mathrm{mg}$.

Table 3. Activities of different keratinases on several proteinaceous substrates.

\begin{tabular}{ccc}
\hline \multirow{2}{*}{ Substrate } & \multicolumn{2}{c}{ Activity of Different Keratinases (U/mg) } \\
\cline { 2 - 3 } & DgeKer & DgeKer-C \\
\hline Soluble keratin & $40,192.30 \pm 230.48$ & $40,408.89 \pm 342.73$ \\
Feather powder & $1494.78 \pm 25.78$ & $1462.54 \pm 71.19$ \\
\hline
\end{tabular}

\subsection{Effects of Metal Ions and Chemical Agents on Keratinases Stability}

The effects of various metal irons with different concentrations $(1 \mathrm{mmol} / \mathrm{L}$ and $5 \mathrm{mmol} / \mathrm{L}$ ) on keratinolytic activity were studied and the results were shown in Table 4 $\mathrm{Mg}^{2+}$ and $\mathrm{Li}^{+}$had stimulatory effect on residual activity of DgeKer; $5 \mathrm{mmol} / \mathrm{L} \mathrm{K}^{+}$caused increased activity of DgeKer (104.11 $\pm 0.14 \%)$. By contrast, other tested metal ions prompted lower stability of DgeKer. $1 \mathrm{mmol} / \mathrm{L}$ and $5 \mathrm{mmol} / \mathrm{L} \mathrm{Ca}^{2+}$ affected the DgeKer stability with residual activity of $94.07 \pm 0.72 \%$ and $83.06 \pm 0.36 \%$, respectively. DgeKer-C was stable $(101.07 \pm 1.37 \%)$ at $5 \mathrm{mmol} / \mathrm{L} \mathrm{Co}^{2+}$. The other tested metal ions had a different decrease on the stability of DgeKer-C with residual activity of $88.25 \pm 0.58 \%$ after pretreatment with $5 \mathrm{mmol} / \mathrm{L} \mathrm{K}^{+}$. Unfortunately, DgeKer and DgeKer-C showed complete inhibition with $5 \mathrm{mmol} / \mathrm{L} \mathrm{Cr}^{3+}$. There was no significant difference $(p>0.05)$ between DgeKer and DgeKer-C after pretreatment with $1 \mathrm{mmol} / \mathrm{L} \mathrm{K}^{+}, \mathrm{Ca}^{2+}, \mathrm{Mn}^{2+}, \mathrm{Ni}^{2+}$ and $5 \mathrm{mmol} / \mathrm{L} \mathrm{Cd}^{2+}$. DgeKer showed better tolerance than DgeKer-C to $\mathrm{Li}^{+}$and $\mathrm{Mg}^{2+}$. However, DgeKer-C was more stable than DgeKer with the pretreatment $\mathrm{Co}^{2+}$ and $\mathrm{Cu}^{2+}$. In general, DgeKer and DgeKer-C had good tolerance to some metal ions.

Table 4. Effects of various metal ions on keratinolytic activity of DgeKer and DgeKer-C.

\begin{tabular}{cccc}
\hline \multirow{2}{*}{ Metal Irons } & $\begin{array}{c}\text { Concentration } \\
(\mathbf{m m o l} / \mathrm{L})\end{array}$ & \multicolumn{2}{c}{ Residual Activity (\%) } \\
\cline { 3 - 4 } & & DgeKer & DgeKer-C \\
\hline Control & 1 & $100.00 \pm 0.27^{\mathrm{m}}$ & $100.00 \pm 3.11^{\mathrm{k}}$ \\
$\mathrm{K}^{+}$ & 5 & $91.77 \pm 0.49^{\mathrm{j}, \mathrm{k}}$ & $87.45 \pm 1.41^{\mathrm{g}}$ \\
& 1 & $104.11 \pm 0.14^{\mathrm{o}}$ & $88.25 \pm 0.58^{\mathrm{g}, \mathrm{h}, *}$ \\
$\mathrm{Li}^{+}$ & 5 & $102.11 \pm 0.59^{\mathrm{n}}$ & $88.60 \pm 0.56^{\mathrm{g}, \mathrm{h}, *}$ \\
& 1 & $113.97 \pm 0.62^{\mathrm{p}}$ & $88.81 \pm 1.72^{\mathrm{g}, \mathrm{h}, *}$ \\
$\mathrm{Mg}^{2+}$ & 5 & $103.35 \pm 1.07^{\mathrm{n}, \mathrm{o}}$ & $93.80 \pm 1.12^{\mathrm{j}, *}$ \\
& 1 & $121.53 \pm 0.75^{\mathrm{q}}$ & $87.09 \pm 0.71^{\mathrm{g}, *}$ \\
$\mathrm{Ca}^{2+}$ & 5 & $94.07 \pm 0.72^{\mathrm{k}}$ & $92.13 \pm 1.18^{\mathrm{i}, \mathrm{j}}$ \\
& 1 & $83.06 \pm 0.36^{\mathrm{g}}$ & $90.65 \pm 0.88^{\mathrm{h}, \mathrm{i}, *}$ \\
$\mathrm{Co}^{2+}$ & 5 & $91.20 \pm 1.66^{\mathrm{j}}$ & $99.20 \pm 3.37^{\mathrm{k}, *}$ \\
& 1 & $92.82 \pm 0.49^{\mathrm{k}, 1}$ & $101.07 \pm 1.37^{\mathrm{k}, *}$ \\
$\mathrm{Mn}^{2+}$ & 5 & $85.07 \pm 0.89^{\mathrm{h}}$ & $80.94 \pm 0.45^{\mathrm{f}}$ \\
& 1 & $64.69 \pm 0.27^{\mathrm{d}}$ & $60.39 \pm 0.96^{\mathrm{b}, *}$ \\
$\mathrm{Ni}^{2+}$ & 5 & $88.33 \pm 0.82^{\mathrm{i}}$ & $86.67 \pm 0.87^{\mathrm{g}}$ \\
& 1 & $91.29 \pm 0.23^{\mathrm{j}}$ & $77.51 \pm 0.66^{\mathrm{e}, *}$ \\
$\mathrm{Cd}^{2+}$ & 5 & $74.93 \pm 0.62^{\mathrm{e}}$ & $86.34 \pm 0.83^{\mathrm{g}, *}$ \\
& & $63.16 \pm 1.02^{\mathrm{c}}$ & $65.32 \pm 1.23^{\mathrm{c}}$ \\
\hline
\end{tabular}


Table 4. Cont.

\begin{tabular}{cccc}
\hline \multirow{2}{*}{ Metal Irons } & $\begin{array}{c}\text { Concentration } \\
(\mathbf{m m o l} / \mathrm{L})\end{array}$ & DgeKer & DgeKer-C \\
\cline { 3 - 4 } & 1 & $79.33 \pm 0.14^{\mathrm{f}}$ & $86.36 \pm 0.09 \mathrm{~g}$,* \\
$\mathrm{Cu}^{2+}$ & 5 & $57.42 \pm 0.41^{\mathrm{b}}$ & $67.21 \pm 0.71^{\mathrm{c}, *}$ \\
$\mathrm{Cr}^{3+}$ & 1 & $86.41 \pm 0.85^{\mathrm{h}}$ & $73.24 \pm 0.31^{\mathrm{d}, *}$ \\
& 5 & $0 \pm 0^{\mathrm{a}}$ & $0 \pm 0^{\mathrm{a}}$ \\
\hline
\end{tabular}

Each value was repeated in triple independent measurements. Superscript letter(s) ${ }^{\mathrm{a}-\mathrm{q}}$ down the column were used to indicate significant difference at $p<0$. The * represents a significant difference $(p<0.05)$ between DgeKer and DgeKer-C with the same pretreatment.

As shown in Table 5, all the surfactants and organic solvent employed negatively impacted on the stability of DgeKer and DgeKer-C, with more drastic effect obtained in the presence of $\beta$-mercaptoethanol. The surfactant (tween- 80 and tween-20) only slightly inhibited DgeKer and DgeKer-C activity. The good tolerance of DgeKer and DgeKer-C to organic solvent DMSO was discovered. The residual activity of DgeKer and DgeKer-C was approximately retained $90 \%$. Furthermore, DgeKer and DgeKer-C showed good stability in $1 \%$ SDS with residual activity of $83.16 \pm 0.54 \%$ and $93.85 \pm 0.56 \%$, respectively. The good tolerance to surfactants as well as organic solvent make DgeKer and DgeKer-C potential enzymes for industrial application. DgeKer was more stable to tween-80 and tween-20 than DgeKer-C, but it was opposite to $1 \%$ SDS and DMSO.

Table 5. Effects of surfactants and organic solvent on keratinolytic activity.

\begin{tabular}{cccc}
\hline \multirow{2}{*}{ Chemical Reagents } & \multirow{2}{*}{ Concentration $(v / v)$ Residual Activity (\%) } \\
\cline { 3 - 4 } & & DgeKer & DgeKer-C \\
\hline Control & $1 \%$ & $100.00 \pm 0.27^{\mathrm{d}}$ & $100.00 \pm 3.11^{\mathrm{d}}$ \\
SDS & $1 \%$ & $83.16 \pm 0.54^{\mathrm{b}}$ & $93.85 \pm 0.56^{\mathrm{c}, \mathrm{d}, *}$ \\
Tween-80 & $1 \%$ & $86.70 \pm 0.62^{\mathrm{c}}$ & $64.59 \pm 4.98^{\mathrm{b}, *}$ \\
Tween-20 & $1 \%$ & $82.68 \pm 0.81^{\mathrm{b}}$ & $71.54 \pm 1.00^{\mathrm{b}, *}$ \\
DMSO & $1 \%$ & $87.75 \pm 0.95^{\mathrm{c}}$ & $92.63 \pm 0.56^{\mathrm{c}, *}$ \\
3-mercaptoethanol & $0 \pm 0^{\mathrm{a}}$ & $15.36 \pm 5.14^{\mathrm{a}, *}$ \\
\hline
\end{tabular}

Each value represents the mean of triple independent measurements. Superscript letter(s) ${ }^{a-d}$ down the column were used to indicate significant difference at $p<0$. The * represents a significant difference $(p<0.05)$ between DgeKer and DgeKer-C with the same pretreatment.

\subsection{Chicken Feather Degradation of DgeKer and DgeKer-C In Vitro}

The necessary steps for keratinase to degrade feathers are the breaking of disulfide bonds and subsequent enzymatic hydrolysis. In this study, a reducing agent of DTT ( $5 \mathrm{mmol} / \mathrm{L}$ ) was added to the degradation system to reduce disulfide bonds of feathers. In addition, we detected the degradation of feathers by keratinases at a high temperature of $70{ }^{\circ} \mathrm{C}$. Tris- $\mathrm{HCl}$ buffer without keratinase was used as a control. Figure 5 shows that DTT (Tris- $\mathrm{HCl}$ with DTT) did not have the ability to degrade intact feathers. Interestingly, the barbules on the feather were degraded by DgeKer after being incubated for $60 \mathrm{~min}$ in the presence of $5 \mathrm{mmol} / \mathrm{L} \mathrm{DTT}$, and significantly degraded after being incubated for $120 \mathrm{~min}$. In contrast, the medium became turbid with obvious softening of barbules after being treated at the same time with DgeKer-C, indicating that DgeKer had stronger feather hydrolysis ability at $70^{\circ} \mathrm{C}$. 
(a)
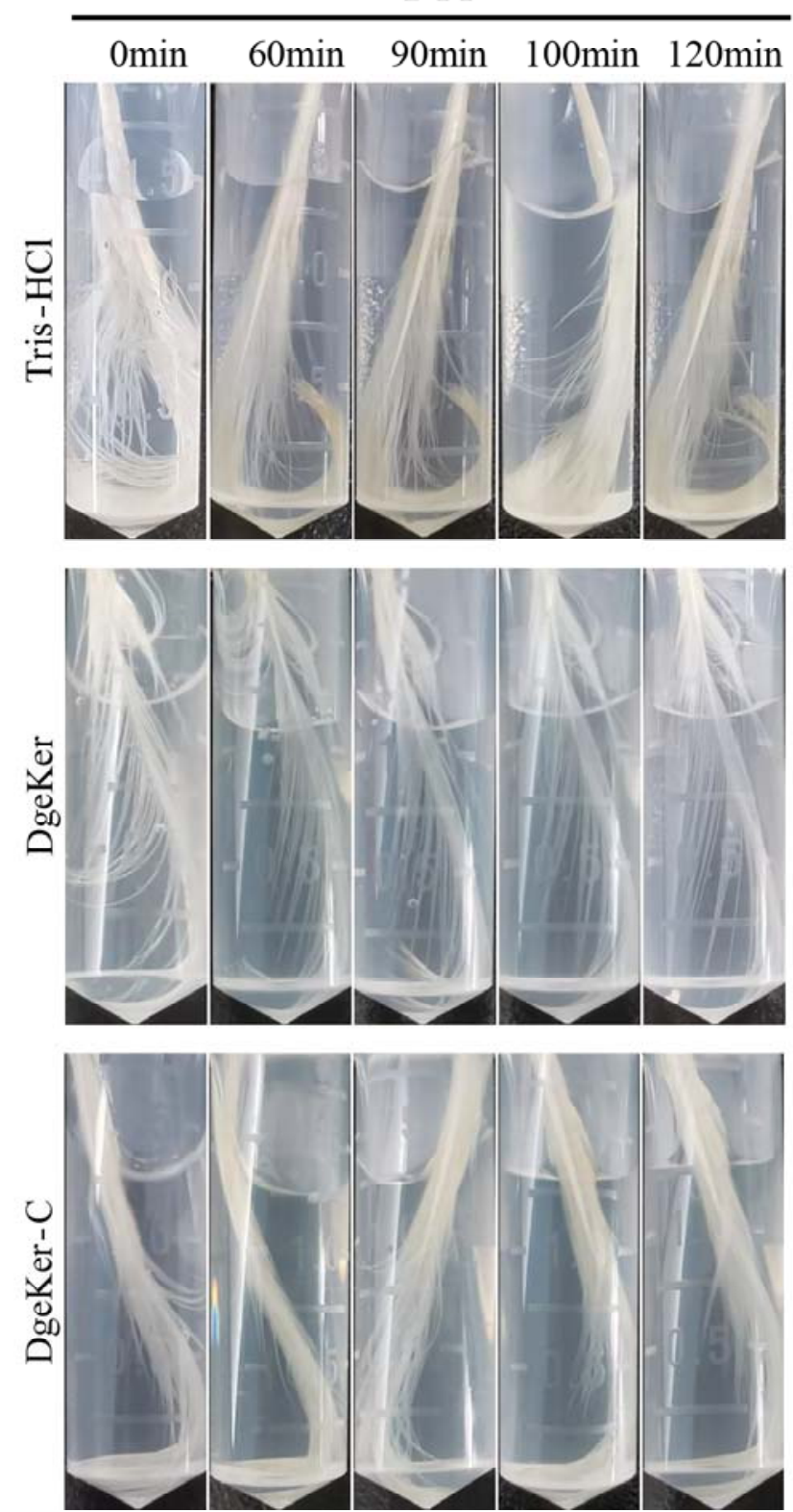

(b)
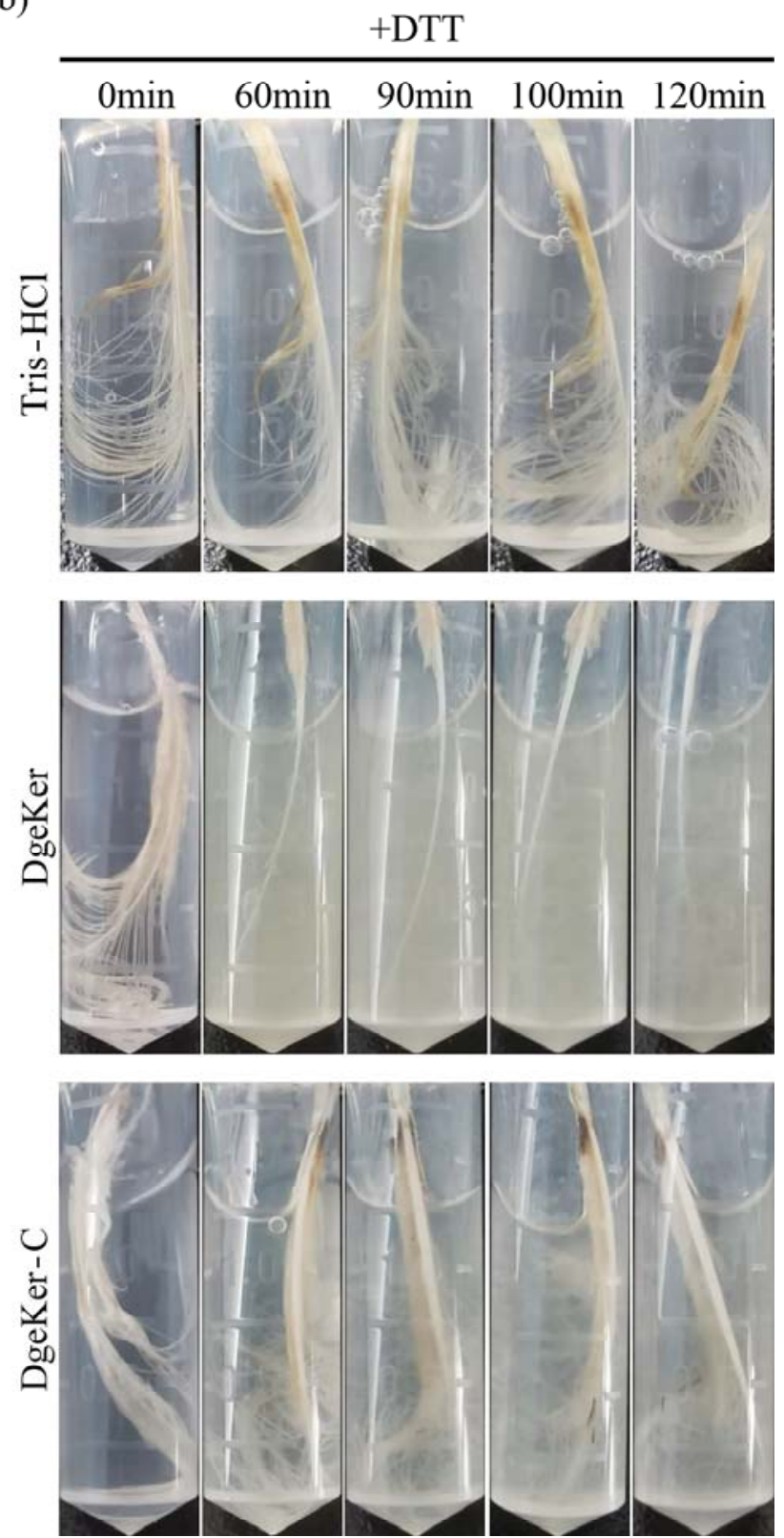

Figure 5. Visual observation of disintegration of intact feathers by the DgeKer and DgeKer-C. Tris- $\mathrm{HCl}$ is a control without keratinase. DTT is a reducing chemical reagent dithiothreitol, which was added to feather degradation system to reduce feather disulfide bonds. (a), The feather degradation in the absence of DTT. "-DTT" represents the system without DTT. (b), The feather degradation in the presence of DTT. "+DTT" represents the system with $5 \mathrm{mmol} / \mathrm{L}$ DTT. The reaction systems were incubated at $70{ }^{\circ} \mathrm{C}$ with shaking.

\section{Discussion}

Extremophile microorganisms are a source of enzymes with good tolerances to extreme conditions [19]. Many keratinases from extremophiles have attractive properties, such as Nocardiopsis [20] and Salicola Marasensis [21], etc. M. twanensis WR-220 is a thermophilic microorganism with a growth temperature of $55-65^{\circ} \mathrm{C}$, and the keratinase in this bacterium also has thermal stability [11]. Many studies have demonstrated the presence of peptidase in the extreme Deinococcus microorganisms [22], such as serine peptidase from D. geothermalis [23] and Deinococcus sp. D7000 [24]. The degrading feather temperature of Deinococcus ficus [25] (feather-degrading bacterium) and D. radiodurans R1 [22] was $30{ }^{\circ} \mathrm{C}$, which is limited for industrial applications. In this study, DgeKer gene was found 
in D. geothermalis, which grow at $50{ }^{\circ} \mathrm{C}$ [14]. According to Figure 2, DgeKer has high homology with peptidases from Calidithermus and Thermus. These bacteria were isolated from extreme environments such as hot springs and are known for their thermal stability. Thermus and Calidithermus bacteria generally grow at medium and high temperature, and their keratinases might have high temperature range and temperature stability, such as MtaKer [11] and aqualysin I [26]. The amylosucrase from Calidithermus timidus has high thermostability with a half-life of $1.09 \mathrm{~h}$ at $70{ }^{\circ} \mathrm{C}$ [27]. As mentioned above, DgeKer has a long C-terminal extension, as with aqualysin-I [26] and VPR from Vibrio sp. PA44 [28]. As Wan-Ling $\mathrm{Wu}$, etc., reported, C-terminal extension only exists in some keratinases from Thermus, Thermococcus, Acinetobacter, Vibrio and Deinococcus, which are generally mesophilic and thermophilic bacteria or extreme [11] bacteria. Therefore, it is valuable to find high temperature-resistant keratinase from $D$. geothermalis.

For industrial needs, it is necessary to overexpress keratinase in E. coli and other cells $[7,29]$. In general, keratinase consists of signal peptide, $\mathrm{N}$-terminal pro-peptide and catalytic domains, and some also carry an extra C-terminal extension [11,30]. The folding of keratinase requires the N-pro-peptide (intramolecular chaperones) to facilitate correct folding and regulate the activation of catalytic domains [31]. Many studies indicate that the N-pro-peptide function as an inhibitor of subtilisin to prevent premature protease activity. The peptide bonds between the intramolecular chaperones and the protease domain are automatically hydrolyzed after the protein folding is complete. However, intramolecular chaperones still bind to proteases in the form of inhibitory complexes [31]. As shown in Figure 3, DgeKer and DgeKer-C could autonomously cleave the N-terminal propeptide to become mature keratinase in E. coli which was consistent with previous [11,31] reports, and the minor bands below the main brand might result from processing or autohydrolysis of the protease. However, the N-terminal cleavage process is currently unclear. Studies have shown that the cleavage process is related to the amino acid preference of the cleavage site [32]. The C-terminal extension is usually located at the C-terminal of some secreted bacterial peptidase, some proteins from metalloproteinase families M4, M9 and M28 and serine protease family S8 were found to contain the C-terminal extension. A phylogenetic tree was constructed based on the C-terminal extended sequence of DgeKer and those of other keratinases. As shown in Figure S1, the C-terminal extension of DgeKer was homologous with those of keratinases from Deinococcus. Obviously, the C-terminal extension was different from PPC (bacterial pre-peptidase C-terminal domain) and PKD (polycystic kidney disease). The modeled structure of C-terminal extension of DgeKer was also built (Figure S2) based on the structure of a keratinase (ProN-TK-SP) from Thermococcus kodakaraensis (3D structure data in Protein Data Bank, PDB ID: 3AFG) [33] which exhibited about 33\% sequence identity with C-terminal extension of DgeKer in the PDB database. The special structure of C-terminal domain of DgeKer was characterized as $\beta$-jelly roll with six $\beta$-strands and loops (Figure S2). According to previous studies, PPC and PKD domains may inhibit keratinase activity [34], enhance heat resistance [10,33], and bind insoluble substrates [35]. However, there are also studies that have the opposite outcome [15]. In general, at present, the mechanism of C-terminal extension is still unclear [36]. Therefore, we constructed the $\mathrm{C}$-terminal extension deletion mutant protein DgeKer-C to explore the effect of C-terminal extension on DgeKer thermal stability and $\mathrm{pH}$ stability.

As shown in Figure 4, DgeKer and DgeKer-C exhibited maximal activity at $70^{\circ} \mathrm{C}$, which was higher than most of the other keratinases [18,32], such as KerA-derived $\left(50{ }^{\circ} \mathrm{C}\right)[30]$ and MtaKer $\left(65^{\circ} \mathrm{C}\right)$ [11]. In terms of thermostability, DgeKer-C performed better than DgeKer (Figure 4). As incubation time extended, the residual enzyme activity of DgeKer-C was higher than DgeKer. DgeKer-C was stable with half-life $\left(t_{1 / 2}\right)$ of $169.10 \mathrm{~min}$, which was 6.4-fold more than KerA. In general, DgeKer and DgeKer-C have high optimal temperature and thermal stability. Feather degradation fermentation is a continuous process and the temperature stability of keratinase is very important for feather degradation. These properties give DgeKer and DgeKer-C greater industrial application potential. 
The optimal $\mathrm{pH}$ of DgeKer and DgeKer-C was 9-10, which was higher than that of most keratinases, such as KerA (pH 8). In the $\mathrm{pH}$ range of 3-7, DgeKer and DgeKer-C were greatly affected by $\mathrm{pH}$, and in the $\mathrm{pH}$ range of $7-11$, neither of them was significantly affected by $\mathrm{pH}$, indicating that DgeKer and DgeKer-C were stable in the $\mathrm{pH}$ range of 7-Studies have shown that the feather degradation process involves sulfitolysis and deamination [1,37], which leads to an elevated $\mathrm{pH}$ in the fermentation environment [38-40]. The $\mathrm{pH}$ of the feather degradation system increased to 8.8 [41]. Therefore, reaction $\mathrm{pH}$ and $\mathrm{pH}$ stability are important factors in industrial applications. The activity and stability of DgeKer under alkaline conditions give this keratinase a certain potential for industrial applications.

DgeKer and DgeKer-C retained high activity over several metal ions, surfactants, reducing agents and organic solvents. In generally, keratinase is stimulated by some metal ions $\left(\mathrm{Ca}^{2+}\right.$ and $\left.\mathrm{Mg}^{2+}\right)[3,42,43]$ which might maintain the active enzyme conformation stabilize the enzyme-substrate complex [38]. $\mathrm{Mg}^{2+}$ increased the enzymatic activity of DgeKer, which is consistent with previous studies. $\mathrm{Ca}^{2+}$ had no positive effect on the enzymatic activity of DgeKer and DgeKer-C, although two hypothetical $\mathrm{Ca}^{2+}$ ion binding sites were predicted in their sequence by NCBI. In general, both DgeKer and DgeKer-C had good metal ion tolerance.

At present, there are several degradation hypotheses about the mechanism of microbial degradation of keratin, but the key step is the degradation of disulfide bonds, so that keratinase can better hydrolyze keratin. Reducing agent DTT can improve the activity of some keratinases [30]. It might be the reducing agent reacting with the substrate rather than keratinases [38]. DTT [44], $\mathrm{Na}_{2} \mathrm{SO}_{3}$ [45], L-cysteine [16] can accelerate the degradation of feathers. In this experiment, $5 \mathrm{mmol} / \mathrm{L}$ DTT was always added to the feather degradation system to promote feather degradation. As shown in Figure 5, it could degrade feathers only when keratinase and DTT exit at the same time, which was consistent with the published feather degradation mechanism. Firstly, the disulfide bond of the feather is opened by the reducing agent, and then the keratinase will degrade [46]. Research has shown that C-terminal extension can facilitate enzymes attach to insoluble substrates to promote degradation [47]. DgeKer-C had the same ability to hydrolyze feather powder as DgeKer (Table 3). However, DgeKer degraded intact feathers faster and better than DgeKer$\mathrm{C}$, which may be attributed to C-terminal extension. Accordingly, the C-terminal residues of MatKer was buried in the active-site cavity and formed a hydrophobic interaction with S1 binding pocked [11], indicating that the C-terminal residues are related to the conformation of the S1 binding pocked. DgeKer and DgeKer-C resulted in different feather degradation. It is possible that the truncated C-terminal extension was too long in this study, which affected the confirmation of DgeKer-C S1 binding pocket. In short, more experiments are needed to explore the function of $\mathrm{C}$-terminal extension.

\section{Conclusions}

In conclusion, the DgeKer and its C-terminal extension truncated enzyme DgeKer-C from slightly thermophilic species $D$. geothermalis showed excellent stability over the alkaline range of $\mathrm{pH}$ and at a temperature of $60^{\circ} \mathrm{C}$, and also displayed excellent tolerance to some metal ions, surfactants and organic solvent, holding promise for industrial applications, such as feather composting. In addition, The C-terminal extension of DgeKer could promote enzyme degradation of insoluble substrates, but has no effect on thermal stability. Indeed, further research is needed to ferment DgeKer in B. subtilis or yeast.

Supplementary Materials: The following are available online at https:/ /www.mdpi.com/article/10 .3390/app11073136/s1, Figure S1: Phylogenetic analysis of C-terminal extension of DgeKer and other keratinases, Figure S2: Modeled structured of C-terminal extension of DgeKer using Pymol software. 
Author Contributions: Conceptualization, Y.T.; Z.Z.; M.L. and J.W.; methodology, Y.T. and Z.Z.; validation, Y.T.; formal analysis, Y.T.; investigation, Y.T.; resources, Z.Z. and W.L.; data curation, Y.T.; writing—original draft preparation, Y.T.; writing—review and editing, Z.Z.; J.W.; S.J.; L.G.; Y.G.; Q.D.; M.Z. and J.H.; visualization, Y.T.; supervision, Z.Z.; M.L. and J.W.; project administration, Z.Z. and J.W.; funding acquisition, J.W. All authors have read and agreed to the published version of the manuscript.

Funding: This work was supported by National Key R\&D Program of China (Nos. 2018YFA0901000 and 2018YFA0901003), the National Transgenic Major Program of China (No. 2019ZX08010-004), the National Natural Science Foundation of China (Nos. 31930004, 31770067 and 31570080). We also appreciate the support of the Agricultural Science and Technology Innovation Program of CAAS (No. CAAS-ZDRW202009).

Institutional Review Board Statement: Not applicable.

Informed Consent Statement: Not applicable.

Data Availability Statement: Data sharing not applicable.

Acknowledgments: Special thanks go to Zhengfu Zhou, Jin Wang and Min Lin for their constructive suggestions on the revision of the article and other authors for their excellent technical support.

Conflicts of Interest: The authors declare no conflict of interest.

\section{References}

1. Korniłłowicz-Kowalska, T.; Bohacz, J. Biodegradation of keratin waste: Theory and practical aspects. Waste Manag. 2011, 31, 1689-1701. [CrossRef] [PubMed]

2. Alba, A.C.; Strauch, T.A.; Keisler, D.H.; Wells, K.D.; Kesler, D.C. Using a keratinase to degrade chicken feathers for improved extraction of glucocorticoids. Gen. Comp. Endocrinol. 2019, 270, 35-40. [CrossRef] [PubMed]

3. Hassan, M.A.; Taha, T.H.; Hamad, G.M.; Hashem, M.; Alamri, S.; Mostafa, Y.S. Biochemical characterisation and application of keratinase from Bacillus thuringiensis MT1 to enable valorisation of hair wastes through biosynthesis of vitamin B-complex. Int. J. Biol. Macromol. 2020, 153, 561-572. [CrossRef]

4. Sharma, R.; Gupta, R. Coupled action of $\gamma$-glutamyl transpeptidase-glutathione and keratinase effectively degrades feather keratin and surrogate prion protein, Sup 35NM. Bioresour. Technol. 2012, 120, 314-317. [CrossRef]

5. Ningthoujam, D.S.; Mukherjee, S.; Devi, L.J.; Singh, E.S.; Tamreihao, K.; Khunjamayum, R.; Banerjee, S.; Mukhopadhyay, D. In vitro degradation of $\beta$-amyloid fibrils by microbial keratinase. Alzheimer's Dement. Transl. Res. Clin. Interv. 2019, 5, 154-163. [CrossRef] [PubMed]

6. Ramirez, D.O.S.; Carletto, R.A.; Tonetti, C.; Giachet, F.T.; Varesano, A.; Vineis, C. Wool keratin film plasticized by citric acid for food packaging. Food Packag. Shelf Life 2017, 12, 100-106. [CrossRef]

7. Li, Q. Progress in Microbial Degradation of Feather Waste. Front. Microbiol. 2019, 10, 2717. [CrossRef]

8. Kanoksilapatham, W.; Intagun, W. A Review: Biodegradation and Applications of Keratin Degrading Microorganisms and Keratinolytic Enzymes, Focusing on Thermophiles and Thermostable Serine Proteases. Am. J. Appl. Sci. 2017, 14, 1016-1023. [CrossRef]

9. Reis, S.V.; Beys-da-Silva, W.O.; Tirloni, L.; Santi, L.; Seixas, A.; Termignoni, C.; Silva, M.V.; Macedo, A.J. The extremophile Anoxybacillus sp. PC2 isolated from Brazilian semiarid region (Caatinga) produces a thermostable keratinase. J. Basic Microbiol. 2020, 60, 809-815.

10. Foophow, T.; Tanaka, S.; Koga, Y.; Takano, K.; Kanaya, S. Subtilisin-like serine protease from hyperthermophilic archaeon Thermococcus kodakaraensis with N- and C-terminal propeptides. Protein Eng. Des. Sel. 2010, 23, 347-355. [CrossRef]

11. Wu, W.-L.; Chen, M.-Y.; Tu, I.-F.; Lin, Y.-C.; EswarKumar, N.; Chen, M.-Y.; Ho, M.-C.; Wu, S.-H. The discovery of novel heat-stable keratinases from Meiothermus taiwanensis WR-220 and other extremophiles. Sci. Rep. 2017, 7, 1-12. [CrossRef] [PubMed]

12. Elleuche, S.; Schröder, C.; Sahm, K.; Antranikian, G. Extremozymes-biocatalysts with unique properties from extremophilic microorganisms. Curr. Opin. Biotechnol. 2014, 29, 116-123. [CrossRef]

13. Promchai, R.; Boonchalearn, A.; Visessanguan, W.; Luxananil, P. Rapid production of extracellular thermostable alkaline halophilic protease originating from an extreme haloarchaeon, Halobacterium salinarum by recombinant Bacillus subtilis. Biocatal. Agric. Biotechnol. 2018, 15, 192-198. [CrossRef]

14. Ferreira, A.C.; Nobre, M.F.; Rainey, F.A.; Silva, M.T.; Wait, R.; Burghardt, J.; Chung, A.P.; Da Costa, M.S. Deinococcus geothermalis sp. nov. and Deinococcus murrayi sp. nov., two extremely radiation-resistant and slightly thermophilic species from hot springs. Int. J. Syst. Evol. Microbiol. 1997, 47, 939-947. [CrossRef]

15. Zhou, C.; Qin, H.; Chen, X.; Zhang, Y.; Xue, Y.; Ma, Y. A novel alkaline protease from alkaliphilic Idiomarina sp. C9-1 with potential application for eco-friendly enzymatic dehairing in the leather industry. Sci. Rep. 2018, 8, 1-18. [CrossRef] 
16. Gong, J.-S.; Ye, J.-P.; Tao, L.-Y.; Su, C.; Qin, J.; Zhang, Y.-Y.; Li, H.; Li, H.; Xu, Z.-H.; Shi, J.-S. Efficient keratinase expression via promoter engineering strategies for degradation of feather wastes. Enzym. Microb. Technol. 2020, 137, 109550. [CrossRef] [PubMed]

17. Yang, L.; Wang, H.; Lv, Y.; Bai, Y.; Luo, H.; Shi, P.; Huang, H.; Yao, B. Construction of a Rapid Feather-Degrading Bacterium by Overexpression of a Highly Efficient Alkaline Keratinase in Its Parent StrainBacillus amyloliquefaciensK. J. Agric. Food Chem. 2016, 64, 78-84. [CrossRef] [PubMed]

18. Ren, Y.; Luo, H.; Huang, H.; Hakulinen, N.; Wang, Y.; Wang, Y.; Su, X.; Bai, Y.; Zhang, J.; Yao, B.; et al. Improving the catalytic performance of Proteinase $\mathrm{K}$ from Parengyodontium album for use in feather degradation. Int. J. Biol. Macromol. 2020, 154, 1586-1595. [CrossRef] [PubMed]

19. Dalmaso, G.Z.L.; Ferreira, D.; Vermelho, A.B. Marine extremophiles: A source of hydrolases for biotechnological applications. Mar. Drugs 2015, 13, 1925-1965. [CrossRef]

20. Bennur, T.; Kumar, A.R.; Zinjarde, S.; Javdekar, V. Nocardiopsis species as potential sources of diverse and novel extracellular enzymes. Appl. Microbiol. Biotechnol. 2014, 98, 9173-9185. [CrossRef] [PubMed]

21. Khoshnevis, N.; Rezaei, S.; Forootanfar, H.; Faramarzi, M.A. Efficient Keratinolysis of Poultry Feather Waste by the Halotolerant Keratinase from Salicola Marasensis. Iran. J. Pharm. Res: IJPR 2019, 18, 1862-1870. [PubMed]

22. Dalmaso, G.Z.; Lage, C.A.; Mazotto, A.M.; de Souza Dias, E.P.; Caldas, L.A.; Ferreira, D.; Vermelho, A.B. Extracellular peptidases from Deinococcus radiodurans. Extremophiles 2015, 19, 989-999. [CrossRef] [PubMed]

23. Pietrow, O.; Panek, A.; Synowiecki, J. Extracellular proteolytic activity of Deinococcus geothermalis. Afr. J. Biotechnol. $2013,12$.

24. Zhang, R.-Y.; Huang, Y.; Qin, W.-J.; Quan, Z.-X. The complete genome of extracellular protease-producing Deinococcus sp. D7000 isolated from the hadal region of Mariana Trench Challenger Deep. Mar. Genom. 2020, 100832. [CrossRef]

25. Zeng, Y.-H.; Shen, F.-T.; Tan, C.-C.; Huang, C.-C.; Young, C.-C. The flexibility of UV-inducible mutation in Deinococcus ficus as evidenced by the existence of the imuB-dnaE2 gene cassette and generation of superior feather degrading bacteria. Microbiol. Res. 2011, 167, 40-47. [CrossRef]

26. Kurosaka, K.; Ohta, T.; Matsuzawa, H. A $38 \mathrm{kDa}$ precursor protein of aqualysin I (a thermophilic subtilisin-type protease) with a C-terminal extended sequence: Its purification and in vitro processing. Mol. Microbiol. 1996, 20, 385-389. [CrossRef] [PubMed]

27. Tian, Y.; Xu, W.; Guang, C.; Zhang, W.; Mu, W. Thermostable Amylosucrase fromCalidithermus timidusDSM 17022: Insight into Its Characteristics and Tetrameric Conformation. J. Agric. Food Chem. 2019, 67, 9868-9876. [CrossRef] [PubMed]

28. Arnórsdóttir, J.; Smáradóttir, R.B.; Magnússon, Ó.T.; Thorbjarnardóttir, S.H.; Eggertsson, G.; Kristjánsson, M.M. Characterization of a cloned subtilisin-like serine proteinase from a psychrotrophic Vibrio species. Eur. J. Biochem. 2002, 269, 5536-5546. [CrossRef]

29. Gopinath, S.C.; Anbu, P.; Lakshmipriya, T.; Tang, T.-H.; Chen, Y.; Hashim, U.; Ruslinda, A.R.; Arshad, M. Biotechnological aspects and perspective of microbial keratinase production. BioMed Res. Int. 2015, 2015. [CrossRef]

30. Fang, Z.; Zhang, J.; Liu, B.; Jiang, L.; Du, G.; Chen, J. Cloning, heterologous expression and characterization of two keratinases from Stenotrophomonas maltophilia BBE11. Process. Biochem. 2014, 49, 647-654. [CrossRef]

31. Shinde, U.; Thomas, G. Insights from Bacterial Subtilases into the Mechanisms of Intramolecular Chaperone-Mediated Activation of Furin. Proprotein Convertases; Springer: Berlin/Heidelberg, Germany, 2011; pp. 59-106.

32. Su, C.; Gong, J.S.; Sun, Y.X.; Qin, J.; Zhai, S.; Li, H.; Li, H.; Lu, Z.M.; Xu, Z.H.; Shi, J.S. Combining Pro-peptide Engineering and Multisite Saturation Mutagenesis to Improve the Catalytic Potential of Keratinase. ACS Synth. Biol. 2019, 8, 425-433. [CrossRef] [PubMed]

33. Foophow, T.; Tanaka, S.-I.; Angkawidjaja, C.; Koga, Y.; Takano, K.; Kanaya, S. Crystal Structure of a Subtilisin Homologue, Tk-SP, from Thermococcus kodakaraensis: Requirement of a C-terminal $\beta$-Jelly Roll Domain for Hyperstability. J. Mol. Biol. 2010, 400, 865-877. [CrossRef] [PubMed]

34. Yan, B.-Q.; Chen, X.-L.; Hou, X.-Y.; He, H.; Zhou, B.-C.; Zhang, Y.-Z. Molecular analysis of the gene encoding a cold-adapted halophilic subtilase from deep-sea psychrotolerant bacterium Pseudoalteromonas sp. SM9913: Cloning, expression, characterization and function analysis of the C-terminal PPC domains. Extremophiles 2009, 13, 725-733. [CrossRef] [PubMed]

35. Chen, X.-L.; Xie, B.-B.; Lu, J.-T.; He, H.-L.; Zhang, Y. A novel type of subtilase from the psychrotolerant bacterium Pseudoalteromonas sp. SM9913: Catalytic and structural properties of deseasin MCP. Microbiology 2007, 153, 2116-2125. [CrossRef]

36. Thornton, J.; Yeats, C.; Bentley, S.; Bateman, A. Faculty of 1000 evaluation for New knowledge from old: In silico discovery of novel protein domains in Streptomyces coelicolor. BMC Microbiol. 2003, 3, 1-20. [CrossRef]

37. Kunert, J.; Kasafírek, E. Preliminary characterization of extracellular proteolytic enzymes of dermatophytes by chromogenic substrates. Med. Mycol. 1988, 26, 187-194. [CrossRef] [PubMed]

38. Brandelli, A.; Daroit, D.J.; Riffel, A. Biochemical features of microbial keratinases and their production and applications. Appl. Microbiol. Biotechnol. 2010, 85, 1735-1750. [CrossRef]

39. Cai, C.G.; Lou, B.G.; Zheng, X.D. Keratinase production and keratin degradation by a mutant strain of Bacillus subtilis. J. Zhejiang Univ. Sci. B 2008, 9, 60-67. [CrossRef]

40. Tiwary, E.; Gupta, R. Medium optimization for a novel 58kDa dimeric keratinase from Bacillus licheniformis ER-15: Biochemical characterization and application in feather degradation and dehairing of hides. Bioresour. Technol. 2010, 101, 6103-6110. [CrossRef]

41. Park, G.-T.; Son, H.-J. Keratinolytic activity of Bacillus megaterium F7-1, a feather-degrading mesophilic bacterium. Microbiol. Res. 2009, 164, 478-485. [CrossRef] 
42. Pereira, J.Q.; Ambrosini, A.; Passaglia, L.M.P.; Brandelli, A. A new cold-adapted serine peptidase from Antarctic Lysobacter sp. A03: Insights about enzyme activity at low temperatures. Int. J. Biol. Macromol. 2017, 103, 854-862. [CrossRef] [PubMed]

43. Bouacem, K.; Bouanane-Darenfed, A.; Jaouadi, N.Z.; Joseph, M.; Hacene, H.; Ollivier, B.; Fardeau, M.-L.; Bejar, S.; Jaouadi, B. Novel serine keratinase from Caldicoprobacter algeriensis exhibiting outstanding hide dehairing abilities. Int. J. Biol. Macromol. 2016, 86, 321-328. [CrossRef] [PubMed]

44. Peng, Z.; Mao, X.; Zhang, J.; Du, G.; Chen, J. Biotransformation of keratin waste to amino acids and active peptides based on cell-free catalysis. Biotechnol. Biofuels 2020, 13, 61. [CrossRef] [PubMed]

45. Pourjavaheri, F.; Pour, S.O.; Jones, O.A.; Smooker, P.M.; Brkljača, R.; Sherkat, F.; Blanch, E.W.; Gupta, A.; Shanks, R.A. Extraction of keratin from waste chicken feathers using sodium sulfide and L-cysteine. Process Biochem. 2019, 82, 205-214. [CrossRef]

46. Gupta, R.; Sharma, R.; Beg, Q.K. Revisiting microbial keratinases: Next generation proteases for sustainable biotechnology. Crit. Rev. Biotechnol. 2012, 33, 216-228. [CrossRef] [PubMed]

47. Miyoshi, S.; Wakae, H.; Tomochika, K.; Shinoda, S. Functional domains of a zinc metalloprotease from Vibrio vulnificus. J. Bacteriol. 1997, 179, 7606-7609. [CrossRef] [PubMed] 